izing the ammoniacal filtrate from the insoluble residue, acidify with an excess of Io cc. of hydrochloric acid and add about 30 grams of granulated test lead. Heat nearly to boiling and stir the lead about until all the copper is precipitated. Now dilute to $200 \mathrm{cc}$. and titrate as described, without removing the lead and precipitated copper.

Denver, Colorado, Februaty $20,1900$.

[CONTRIBUTIONS FROM THE HAVEMEYER LABORATORIES OF COLUMBI 1 UNIVERSITY, NO. 2I.]

\title{
A NEW BRIDGE ARRANGEMENT FOR THE DETERMI- NATION OF ELECTROMOTIVE FORCE BY AID OF THE LIPPMANN ELECTROMETER.
}

\author{
By J. LivingstoN R. MORGaN.
}

Received Fabruary 3, Ig00.

TH

$\mathrm{HE}$ two-bridge arrangements given by Ostwald ${ }^{1}$ for the measurement of electromotive force by the aid of the Lippmann electrometer are the only two at present in use for primary cells. When an accumulator is used, it is only necessary to connect it through a meter of manganine wire and to compensate the cell to be measured by a fraction of the source taken off from the wire by a sliding contact." If a primary cell were used in this way the results would not be accurate, owing to the decrease in the electromotive force of the cell due to the small resistance of the wire (50 ohms at most). Of the two methods in which primary cells may be used as a source, we may say that each is good for its purpose but that neither is of general utility. The method using the sliding contact as already described for an accumulator necessitates the use of a spool at one end of the bridge wire, which contains thirteen times the resistance of the bridge wire. In this way the cell is connected through 700 ohms ( $4 \times 50$ ) so that its electromotive force remains constant during the operation. By this, however, the drop in potential at the ends of the wire, with a Leclanché cell (I.4 volts), is only 0. I volt, so that nothing larger than that can be measured, unless some elaborate device is provided by which another known electromotive force may be placed against the one to be

1 Hand- und Filfsuch zur Ausfihrung physico-chemischer Messunger, 252-253.

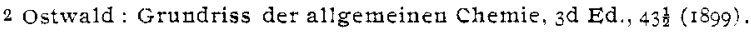


measured so as to make the difference between the two less than o. I volt. The accuracy of the arrangement, however, is great, for each millimeter represents 0.000 I volt if the electrometer is sufficiently delicate.

In the other method the cell is closed through a resistance box of $1000 \mathrm{ohms}$ provided with nine coils of $100 \mathrm{ohms}$ and ten of ro ohms each. If the Leclanche cell is cut down to one volt by a suitable resistance, then each of the 10-0hm coils represents O.oI volt, while each of the Ioo-ohm coils represents 0. I volt. By means of two plugs, any fraction of the I volt may thus be placed against the electromotive force to be measured until it is compensated. Thousandths of a volt may be approximated by the movement of the meniscus of the electrometer in opposite directions, caused by the connection first to a ro-ohm coil which is just too high, and then to one which is just too low. This, however, is not to be used with very delicate electrometers for o.or volt may cause the meniscus to go out of the field. By the box method, then, it is possible to measure any electromotive force, even above $I$ volt if a battery of $\mathrm{I}$-volt cells is at hand, with an accuracy of 0.01 volt and to approximate to 0.00 I volt.

We see then that the two methods separately give satisfactory results, but that it is inconvenient, to say the least, to measure anything above 0 .I volt, with an accuracy of more than about 0.002 volt. The object of this paper is to describe a method which can take the place of both those described, and measure directly, if the electrometer is delicate enough, any electromotive force with an accuracy of 0.001 volt, and can also be used at any time for rougher work just as conveniently as the box method.

The current goes first through a box in which there are 13 coils of wire and then through a bridge wire of manganine ( $I$ meter $\times 0.1 \mathrm{~mm}$., resistance 50 ohms). Each of the 13 coils is of the same resistance as the wire on the bridge and may be made up of an equal length of the same wire properly insulated. On the wire there is a slider which is always in contact with the wire, while any number of the 13 coils can be brought into use in the same way as in the case of the box already mentioned. By this arrangement we have what is practically a bridge 14 meters 
long of which the one meter laid out can be made any fourteenth from I to I4. The wire from the plug on the coils and the one from the sliding contact are treated just as those on the box are (see figure). To make a determination, the slide on the wire is placed at one end and the plug connected with the coils is moved until one post gives too great an electromotive force while the one next below it gives too small a one. The plug is then left on this latter and the sliding contact on the bridge wire

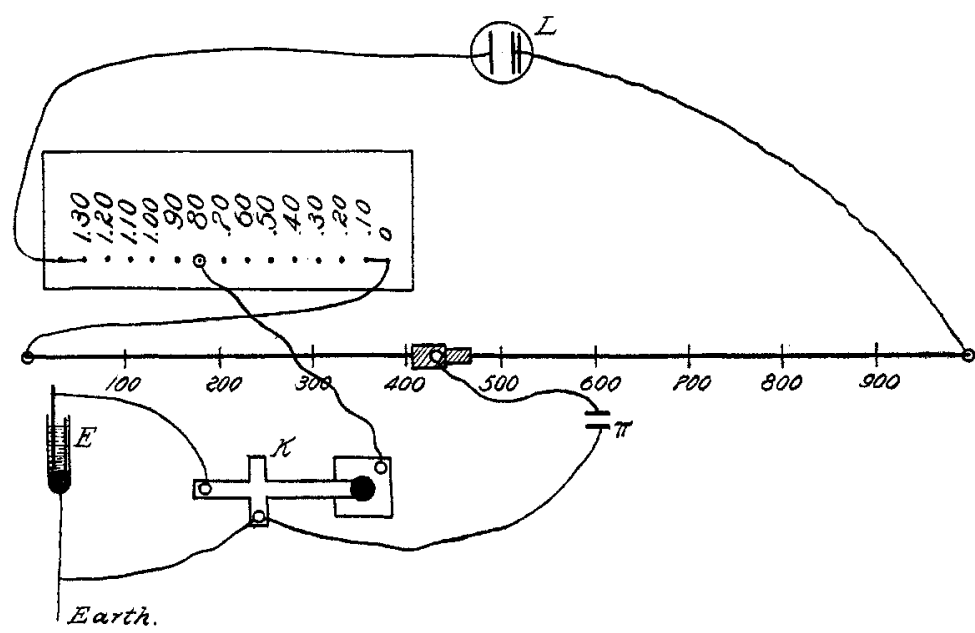

is moved until the meniscus in the electrometer is motionless when the key is pressed. To the number opposite the coil, is then added the same number of ten-thousandths as there are millimeters in the reading on the bridge. This number when multiplied by the total drop of potential at the connections to the Leclanché gives the value in volts. Possibly the use of a storage cell in the way described is to be preferred; although these cells are uncertain as a rule in their results, still this method just described has received a good trial and can be recommended whenever a primary cell is to be used. 